\title{
INTELLECTUAL CAPITAL IMPACT PADA FINANCIAL PERFORMANCE PERBANKAN YANG TERDAFTAR DI BURSA EFEK INDONESIA
}

\author{
Yateno \\ Universitas Muhammadiyah Metro \\ Email : yatno.apta@gmail.com
}

\begin{abstract}
FIDUSIA
Jurnal Ilmiah Keuangan dan Perbankan

ISSN Cetak : 2621-2439

ISSN Online : 2621-2447
\end{abstract}

Keyword: Intellectual Capital, Financial Performance, Return on Assets and Return On Equity

\begin{abstract}
The purpose of this research was to examine the effect of intellectual capital on Return On Assets, and Return On Equity. The population of this research is manufacturing companies listed on the Stock Exchange the period 2016-2018, a total sample of companies amounted to 72 samples were taken by using purposive sampling method. The method of analysis in this research is multiple linear regression analysis. The results of this study indicate that intellectual capital significant positive effect on ROA. This condition occurs because when intellectual capital is getting better, the public trust in the company, the better, so that the products or services offered by the company is accepted by the community and increasing revenue. Intellectual capital is significant positive effect on ROE. This condition occurs because the intellectual capital increases, the company has been using its capital more effectively to improve human resources, so that the performance of employees to generate increasing profits.
\end{abstract}

Keyword: Intellectual Capital, Financial Performance, Return on Assets and Return On Equity 


\section{PENDAHULUAN}

Kinerja Perbankan dan lembaga keuangan lainnya sangat dinamis karena perubahan perekonomian suatu negara berpengaruh terhadap lembaga keuangan di negara tersebut. Perkembangan lembaga keuangan di Indonesia tumbuh cukup baik, terutama pada lembaga keuangan konvensional. Perbankan menjadi lembaga paling besar dan menjadi salah satu pendukung pertumbuhan ekonomi nasional. Bank umum adalah bank yang melaksanakan kegitan usaha secara konvensional atau berdasarkan prinsip syariah yang dalam kegiatannya memberikan jasa dalam lalu lintas pembayaran (Peraturan Bank Indonesia Nomor 9/PBI/2007). Jasa yang diberikan oleh bank umum bersifat umum, artinya dapat memberikan seluruh jasa perbankan yang ada. Seiring dengan makin ketatnya persaingan antar perusahaan akibat adanya pasar bebas dan globalisasi yang menuntut perusahaan untuk mengubah strategi bisnisnya yang sebelumnya berdasarkan pada tenaga kerja (labor-based business) menjadi bisnis yang berdasarkan pada pengetahuan (knowledge based business).

Komponen dari aset tidak berwujud salah satunya dikenal dengan intellectual capital. Kesadaran tentang pentingnya peran intellectual capital bagi pertumbuhan perusahaan membuat perhatian perusahaan terhadap pengelolaan intellectual capital semakin besar. Beberapa tahun terakhir banyak perusahaan yang telah melengkapi laporan kinerjanya dengan laporan intellectual capital.

Kontribusi penelitian ini adalah perusahaan-perusahaan perbankan mampu dan bisa memahami karakteristik dari Intellectual Capital (IC) yang membutuhkan perhatian guna peningkatan kinerja dan sebaliknya perusahaan bisa mendapatkan informasimengenai komponen Intellectual Capital (IC) yang merupakan penggerak utama atau pencipta nilai perusahaan perbankan. Selanjutnya hal ini bisa diaplikasikan sebagai strategi perusahanperuahaan perbankan.

Kinerja perusahaan akan dijadikan sebagai dasar pengambilan keputusan bagi pihak internal maupun eksternal untuk mencapai tujuan perusahaan. Kinerja keuangan perusahaan sangat penting untuk diukur dan diketahui bagaimana tingkat perkembangannya karena merupakan tolak ukur keberhasilan perusahaan. Informasi tentang kinerja keuangan berguna untuk menetapkan kebijakan yang akan diambil oleh pihak manajemen suatu perusahaan. Menghadapi persaingan yang semakin ketat, maka masuknya perusahaan asing ke pasar Indonesia menuntut perusahaan dalam negeri untuk memperbaiki kinerja perusahaan.

Menurut pendapat Chen et al (2005) dalam Ulum (2008) menyarankan sebuah pengukuran tidak langsung terhadap Intellectual Capital yaitu dengan mengukur efisiensi dari nilai tambah yang dihasilkan oleh kemampuan intelektual perusahaan yang dinamakan VAIC. VAIC merupakan metode untuk mengukur kinerja Intellectual Capital perusahaan. Metode VAIC ini relatif mudah dan memungkinkan untuk dilakukan karena menggunakan data yang ada dalam laporan keuangan tahunan perusahaan. Metode VAIC akan menggambarkan seberapa besar Intellectual Capital menambah nilai perusahaan dari penggunaan aset tersebut. Penggunaan metode VAIC akan memberikan peluang bagi 
perusahaan dan stakeholder untuk mengetahui seberapa besar aset berwujud dan tidak berwujud memberikan nilai dan seberapa efisien dalam memberikan keuntungan perusahaan.

\section{LANDASAN TEORI DAN PENGEMBANGAN HIPOTESIS}

\section{Resources Based Theory}

Resources Based Theory pertama kali disampaikan oleh Wernerfelt (1984) dalam artikel pionernya yang berjudul "A Resources- based view of the firm". Resources Based Theory adalah sumber daya pada perusahaan yang dapat di jadikan keunggulan bersaing dan mampu mengarahkan perusahaan untuk memiliki kinerja jangka panjang yang baik. Teori ini membahas tentang sumber daya yang dimiliki perusahaan dan bagaimana perusahaan tersebut dapat mengolah, dan memanfaatkan sumber daya yang dimiliki. Sumber daya yang dimiliki perusahaan dapat menciptakan nilai tambah bagi perusahaan dalam mengambil peluang kesempatan dan menghadapi ancaman sehingga perusahaan memiliki keunggulan kompetitif yang berbeda dengan perusahaan lain untuk menguasai pasar.

Menurut Barney (2001) mengkategorikan tiga jenis sumber daya yaitu modal sumber daya fisik (teknologi, pabrik dan peralatan), modal sumber daya manusia (pelatihan, pengalaman, wawasan), dan modal sumber daya organisasi (struktur formal). Intellectual Capital (IC) memenuhi kriteria-kriteria sebagai sumber daya yang unik untuk menciptakan keunggulan kompetitif dan meningkatkan kinerja keuangan perusahaan.

Resource based theory meyakini bahwa perusahaan akan mencapai keunggulan apabila perusahaan tersebut memiliki sumber daya yang unggul. Menciptakan dan mempertahankan keunggulan kompetitif, perusahaan dapat mengembangkan sumber daya yang dimiliki agar bernilai, tidak mudah ditiru, tidak tergantikan, dapat diandalkan dan berbeda dari perusahaan lain. Hal tersebut yang membuat Intellectual Capital sebagai kunci untuk menciptakan value added bagi perusahaan.

\section{Intellectual Capital (IC)}

Intellectual Capital (IC) merupakan materi intelektual yang telah diformulasikan untuk menciptakan kekayaan dengan menghasilkan suatu asset yang bernilai tinggi (Ulum, 2009). Di Indonesia, fenomena Intellectual Capital (IC) mulai berkembang setelah munculnya PSAK No.19 (revisi 2000) tentang aset tidak berwujud. Menurut PSAK No. 19, aset tidak berwujud adalah aset non-moneter yang dapat diidentifikasikan dan tidak mempunyai wujud fisik serta dimiliki untuk digunakan dalam menghasilkan atau menyerahkan barang atau jasa, disewakan pada pihak lainnya, atau untuk tujuan administratif (IAI,2007).

Intellectual Capital (IC) telah mendapat perhatian banyak pihak meskipun tidak dinyatakan secara empiris, semakin meningkat perhatian terhadap Intellectual Capital (IC) berarti semakin meningkat kesadaran perusahaan mengenai Intellectual Capital (Ulum, 2008). Oleh karena itu, jika perusahaan mengacu pada bisnis berdasarkan pengetahuan, maka 
perusahaan di Indonesia dapat bersaing menggunakan keunggulan kompetitif yang diperoleh melalui inovasi kreatif yang dihasilkan oleh Intellectual Capital (IC) perusahaan.

Intellectual Capital (IC) merupakan asset yang tidak terlihat dan merupakan gabungan dari faktor manusia, proses dan pelanggan yang memberikan keunggulan kompetitif bagi perusahaan. Intellectual Capital (IC) diakui sebagai salah satu intangible asset yang sangat penting di era informasi dan pengetahuan. Intellectual Capital (IC) oleh Nahapiet dan Goshal (1998) dalam Sugeng (2002), mengacu pada pengetahuan dan kemampuan yang dimiliki oleh kolektivitas sosial seperti sebuah organisasi, komunitas intelektual, atau praktik profesional. Intellectual Capital (IC) mewakili sumber daya yang bernilai dan berkemampuan untuk bertindak berdasarkan pada pengetahuan.

Sedang menurut Roos et al. (1997) dalam Ulum, 2008) menyatakan bahwa IC termasuk semua proses dan aset yang tidak biasanya ditampilkan pada neraca dan seluruh aset tidak berwujud (merek dagang, paten dan merek) yang dianggap sebagai metode akuntansi modern.

Selanjutnya menurut Bontis et al. (2000) dalam Ulum (2008) menyatakan bahwa hasil penelitiannya, IC dapat diidentifikasi menjadi tiga komponen utama, yaitu: (a) Human Capital (HC), Human capital adalah kompetensi, pengetahuan,keterampilan,dan kepribadian yang dimiliki oleh karyawan. Human capital berasal dari pendidikan dan pengalaman yang dapat menghasilkan inovasi melalui kreatifitas dan keterampilan yang dimiliki karyawan. (b) Structural capital (SC) yang meliputi seluruh non-human storehouses of knowledge dalam organisasi" seperti database, organisational charts, process manuals, strategies, routines dan segala hal yang membuat nilai perusahaan lebih besar daripada nilai materialnya. (c) Customer Capital (CC) merupakan hubungan antara perusahaan dengan semua pihak yang mempunyai hubungan dengan perusahaan. Pihak diluar perusahaan yang berbisnis dengan perusahaan dan mempunyai hubungan baik dengan perusahaan disebut dengan customer capital.

Resource based theory meyakini bahwa perusahaan akan mencapai keunggulan apabila perusahaan tersebut memiliki sumber daya yang unggul. Menciptakan dan mempertahankan keunggulan kompetitif, perusahaan dapat mengembangkan sumber daya yang dimiliki agar bernilai, tidak mudah ditiru, tidak tergantikan, dapat diandalkan dan berbeda dari perusahaan lain. Hal tersebut yang membuat Intellectual Capital sebagai kunci untuk menciptakan value added bagi perusahaan.

\section{Pengertian Value Added Intellectual Coefficient (VAIC ${ }^{\mathrm{TM}}$ )}

Metode VAIC ${ }^{\text {TM }}$ merupakan metode yang dikembangkan oleh Pulic pada tahun 1998 yang didesain untuk menyajikan informasi tentang value creation efficiency yang dimiliki perusahaan baik aset berwujud (tangible asset) maupun aset tidak berwujud (intangible assets). VAICTM ini dimulai dari kemampuan perusahaan dalam menciptakan value added (VA). VA diperoleh dari selisih antara output dan input (Pulic, 1999 dalam Ulum, 2018). 
Menurut Tan et al. (2007) dalam Ulum (2008), menyatakan bahwa Output (OUT) merepresentasikan pendapatan seluruh pendapatan yang diperoleh perusahaan, sedangkan input (IN) mencakup seluruh beban yang dipergunakan dalam memperoleh pendapatan. Lebih lanjut, Tan et al. (2007) dalam Ulum (2008) menyatakan bahwa beban karyawan (labour expenses) tidak termasuk dalam beban perusahaan karena peran aktifnya dalam proses penciptaan nilai. Jadi, dapat disimpulkan aspek kunci dalam model Pulic menjadikan tenaga kerja sebagai identitas penciptaan nilai (value creation).

Komponen-komponen Value Added Intellectual Coefficient (VAICTM) yaitu: (a). Value Added Capital Employed Coefficient (VACA), (b). Value Added Human Capital Coefficient (VAHU), (c). Structural Capital Value Added Coefficient (STVA).

Value added adalah indikator paling objektif untuk menilai keberhasilan bisnis dan menunjukkan kemampuan perusahaan dalam penciptaan nilai (value creation). VA dipengaruhi oleh efisiensi dari Human Capital (HC) yang biasa disebut VAHU, menunjukkan angka kontribusi karyawan terhadap peningkatan nilai tambah perusahaan dan Structural Capital (SC) yang biasa disebut STVA. Hubungan lainnya dari VA adalah capital employed (CE), yang dalam hal ini dilabeli dengan VACA. VACA adalah indikator untuk VA yang diciptakan oleh satu unit dari physical capital. VAICTM adalah penjumlahan Capital Employed Efficiency dengan Intelectual Capital Efficiency yang terdiri dari Human Capital Efficiency dan Structural Capital Efficiency. VAICTM merupakan total efisiensi atau intellectual ability perusahaan. Indikator VAICTM yang tinggi merefleksikan kemampuan perusahaan untuk mengelola potensi modal intelektual yang dimilikinya dalam rangka mendatangkan nilai tambah (Santoso, 2012) Keunggulan dari VAICTM adalah data yang dibutuhkan relatif mudah diperoleh dari berbagai sumber dan jenis perusahaan. Data yang dibutuhkan untuk menghitung berbagai rasio tersebut adalah angka-angka keuangan yang standar yang umumnya tersedia dari laporan keuangan perusahaan (Wijayanti, 2010).

\section{Intellectual Capital dan Kinerja Keuangan Perusahaan (ROA)}

Pendekatan berbasis sumber daya (resource-based view of the firm/RBV) atau resource-based theory menyatakan bahwa perusahaan akan unggul dalam persaingan usaha dan mendapatkan kinerja keuangan yang baik dengan cara memiliki, menguasai dan memanfaatkan aset-aset strategis yang penting (aset berwujud dan tidak berwujud). Intellectual Capital merupakan kekayaan intelektual yang berpusat pada sumber daya manusia yang berfungsi meningkatkan daya saing perusahaan. Jika kemampuan sumber daya manusia semakin baik, maka diharapkan akan menghasilkan kinerja yang baik bagi perusahaan, sehingga profitabilitas Return On Asset semakin meningkat.

Intellectual Capital diukur dengan metode VAICTM. Ulum et al., (2008), Intellectual Capital diyakini dapat berperan penting dalam peningkatan nilai perusahaan maupun kinerja keuangan. Semakin tinggi ROA suatu perusahaan semakin tinggi pula keuntungan yang dicapai perusahaan tersebut dan semakin baik posisi perusahaan dari segi penggunaan aset. 
Hasil dari penelitian yang dilakukan oleh Comepa et al. (2011) menunjukkan bahwa Intellectual Capital (IC) berpengaruh positif terhadap kinerja keuangan yang diproksikan dengan Return on assets (ROA). Selanjutnya Penelitian Fajarini W., I. S., dan Firmansyah, R. (2012), Kurniawan (2013) membuktikan bahwa Intellectual Capital (VAICTM) berpengaruh positif terhadap kinerja keungan perusahaan (ROA). Berdasarkan hasil penelitian tersebut maka diajukan hipotesis sebagai berikut:

\section{H1: Intellectual Capital berpengaruh positif dan signifikan terhadap kinerja keuangan perusahaan (ROA).}

\section{Intellectual Capital dan Kinerja Keuangan Perusahaan (ROE)}

Intellectual capital adalah aset tak berwujud yang memegang peran penting dalam meningkatkan daya saing perusahaan dan juga dimanfaatkan secara efektif untuk meningkatkan keuntungan perusahaan. Pengelolaan Sumber Daya Manusia (SDM) yang baik dalam perusahaan dapat meningkatkan produktivitas karyawan yang akan meningkatkan pendapatan dan profit perusahaan. Produktivitas karyawan dan profit perusahaan yang semakin meningkat menunjukkan bahwa karyawan semakin baik dalam mengelola modal perusahaan. Hal ini dapat menciptakan kepercayaan stakeholder pada perusahaan tersebut, dengan terciptanya kepercayaan, maka akan menarik investor untuk menanamkan modal di perusahaan, sehingga laba dari total ekuitas pemegang saham yang diukur dengan return on equity (ROE) akan turut meningkat. Salah satu rasio yang dipergunakan untuk mengukur kemampuan perusahaan dalam menghasilkan laba adalah Return on Equity (ROE). ROE mencerminkan kemampuan perusahaan dalam menghasilkan laba berdasarkan ekuitas yang dimilikinya.

Return on Equity ROE mengukur efisiensi suatu perusahaan dari keuntungan yang dihasilkan dari setiap unit ekuitas pemegang saham Wijayanti (2012). ROE menunjukkan seberapa baik suatu perusahaan menggunakan dana investasi (Intellectual capital) untuk menghasilkan pertumbuhan pendapatan. Hasil penelitian Fajarini dan Firmansyah (2012), membuktikan bahwa Intellectual capital berpengaruh positif terhadap ROE. Hal ini dibuktikan oleh penelitian yang dilakukan Ivan Herdyanto dan Mohamad Nasir (2013) bahwa IC berpengaruh positif terhadap ROE. Semakin tinggi IC, maka ROE semakin meningkat. Berdasarkan uraian di atas, maka di kemukakan hiposteis:

\section{H2: Intellectual Capital berpengaruh positif dan signifikan terhadap kinerja keuangan perusahaan ( $\mathrm{ROE})$.}




\section{Kerangka Konseptual}

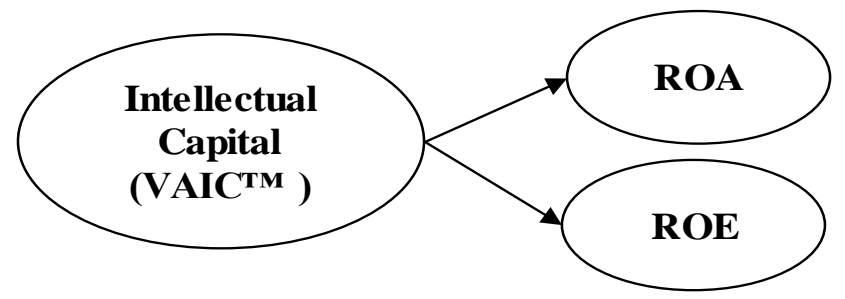

Gambar 1. Konseptual penelitian

\section{Kinerja Keuangan}

Kinerja dapat diartikan sebagai prestasi yang dicapai perusahaan dalam periode tertentu yang mencerminkan tingkat kesehatan suatu perusahaan Sukhemi (2007). Kinerja merupakan sebuah gambaran prestasi yang akan dicapai suatu perusahaan dalam kegiatan operasional. Kinerja keuangan perusahaan berupa gambaran dari kondisi keuangan perusahaan yang dianalisis menggunakan rasio keuangan. Dari analisis tersebut dapat diketahui bagaimana keadaan keuangan perusahaan yang mencerminkan prestasi kerja. Penilaian kinerja keuangan adalah salah satu cara untuk memenuhi kewajiban kepada penyandang dana dan untuk mencapai tujuan perusahaan.

Sedangkan kinerja keuangan merupakan hasil dari suatu proses yang mengorbankan berbagai sumber daya untuk kelangsungan hidup perusahaan. Salah satu parameter kinerja tersebut adalah laba. Untuk memperoleh laba, perusahaan harus melakukan kegiatan operasional dimana kegiatan oprasional tersebut dapat terlaksana jika perusahaan mempunyai sumber daya. Pertumbuhan laba yang terus meningkat dari tahun ke tahun, maka akan memberikan sinyal positif mengenai kinerja keuangan. Menurut Mulyadi (2007) Kinerja didefinisikan sebagai keberhasilan personel dalam mewujudkan sasaran strategik di empat perspektif yaitu, keuangan, pelanggan, proses, serta pembelajaran dan pertumbuhan".

Penilaian kinerja keuangan dapat menggunakan ukuran atau tolak ukur tertentu. Ukuran yang lazim digunakan adalah rasio atau indeks yang menghubungkan dua data keuangan. Jenis perbandingan rasio masa lalu, saat ini dan masa yang akan datang untuk perusahaan yang sama. Rasio keuangan menjadi alat analisis data yang paling sering digunakan dalam dunia keuangan. Rasio ini menghubungkan berbagai perkiraan pada laporan keuangan sehingga dapat mempresentasikan kondisi keuangan dan hasil operasi perusahaan.

Kinerja Perbankan merupakan hal penting yang harus dicapai oleh setiap perusahaan, karena kinerja merupakan cerminan dari kemampuan perusahaan dalam mengelola dan mengalokasikan sumber dayanya. Selain itu tujuan pokok penilaian kinerja adalah untuk memotivasi karyawan dalam mencapai sasaran organisasi dan dalam memenuhi standar perilaku yang telah ditetapkan sebelumnya, agar membuahkan tindakan dan hasil yang diharapkan Dendawijaya (2009). Jadi, kinerja (performance) bank adalah gambaran mengenai prestasi kerja perusahaan atau kemampuan kerja perusahaan atas kegiatan operasional yang dilakukan. Oleh karena itu, untuk mengetahui prestasi yang dicapai 
perusahaan perlu dilakukan penilaian terhadap kinerja perusahaan dalam kurun waktu tertentu.

Rentabilitas bank adalah kemampuan suatu bank untuk memperoleh laba yang dinyatakan dalam persentase Hasibuan (2006). Analisis rasio rentabilitas bank adalah alat untuk menganalisis atau mengukur tingkat efisiensi usaha dan profitabilitas yang dicapai oleh bank yang bersangkutan. Selain itu, rasio-rasio dalam kategori ini dapat pula digunakan untuk mengukur tingkat kesehatan bank Dendawijaya (2009). Faktor utama yang mempengaruhi profitabilitas bank adalah manajemen. Seluruh manajemen suatu bank baik mencakup manajeman permodalan, manajemen kualitas aktiva, manajemen umum, manajemen rentabilitas dan manajemen likuiditas pada akhirnya akan mempengaruhi dan bermuara pada perolehan laba perusahaan perbankan (Aristya, 2010).

\section{METODE PENELITIAN}

\section{Jenis dan Sumber Data}

Jenis data penelitian ini adalah data sekunder. Data sekunder dalam penelitian ini diperoleh dari laporan tahunan (annual report) perusahaan tahun 2016-2018 yang terdaftar di Bursa Efek Indonesia dan Indonesian Capital Market.

\section{Populasi dan Sampel Penelitian}

Populasi dalam penelitian ini adalah seluruh perusahaan manufaktur yang terdaftar di Bursa Efek Indonesia (BEI) pada tahun 2016-2018. Metode pemilihan sampel menggunakan metode purposive sampling dengan kriteria sebagai berikut:

1. Terdaftar sebagai perusahaan manufaktur yang tercatat di Bursa Efek Indonesia pada tahun 2016-2018.

2. Tidak mengalami delisting (keluar) dari Bursa Efek Indonesia selama 3 tahun berturutturut yaitu 2016-2018.

3. Tidak mengumumkan laporan keuangan dalam bentuk dolar.

4. Memiliki data yang lengkap guna penelitian.

Tabel 1. Distribusi Sampel

\begin{tabular}{|c|l|c|}
\hline No & \multicolumn{1}{|c|}{ Keterangan } & Jumlah Perusahaan \\
\hline \hline 1 & $\begin{array}{l}\text { Perusahaan Manufaktur yang terdaftar di BEI periode } \\
\text { Tahun 2016-2018 }\end{array}$ & 170 \\
\hline 2 & $\begin{array}{l}\text { Perusahaan yang yang tidak mempublikasikan Lapaoran } \\
\text { keuangan per 31 Desember periode tahun 2016-2018 }\end{array}$ & 16 \\
\hline 3 & $\begin{array}{l}\text { Perusahaan membuat laporan keuangan yang publikasikan } \\
\text { dalam bentuk dollar }\end{array}$ & 25 \\
\hline 4 & $\begin{array}{l}\text { Perusahaan mengalami kerugian selama periode dilakukan } \\
\text { riset }\end{array}$ & 70 \\
\hline
\end{tabular}




\section{Definisi operasional dan Pengukuran variabel}

\section{Intellectual Capital (X)}

Intellectual capital adalah aset tak berwujud yang memainkan peran penting dalam meningkatkan daya saing perusahaan dan juga dimanfaatkan secara efektif untuk meningkatkan keuntungan perusahaan. Kinerja IC yang diukur berdasarkan value added yang dibentuk oleh phsycal capital (VACA), human capital (VAHU), dan structural capital (STVA). Perpaduan dari ketiga value added tersebut disimbolkan dengan nama VAIC yang dikembangkan oleh Pulic (1998, 1999, 2000). Formulasi dan tahapan perhitungan VAIC ${ }^{\mathrm{TM}}$ dalam (Rismawati dan Sanjaya, 2012) dijelaskan sebagai berikut:

\section{Tahap pertama}

Menghitung value added (VA). Value Added dihitung sebagai selisih antara output dan input.

$$
\text { VA= Out }- \text { In }
$$

\section{Keterangan:}

Out $=$ output $:$ total penjualan dan pendapatan lain .

In = input : beban penjulan dan biaya-biaya lain (selain beban karyawan).

\section{Tahap kedua}

Menghitung Capital Employ (CE), Human Capital (HC), Structural Capital (SC)

$$
\begin{aligned}
& \mathrm{CE}=\text { Ekuitas }+ \text { Laba Bersih } \\
& \mathrm{HC}=\text { Beban Karyawan } \\
& \mathrm{SC}=\text { VA-HC }
\end{aligned}
$$

\section{Tahap ketiga}

Menghitung value added capita; employe (VACA), value added human capital (VAHU) dan structural capital value added (STVA).

$$
\begin{aligned}
& \mathrm{VACA}=\mathrm{VA} / \mathrm{CE} \\
& \mathrm{VAHU}=\mathrm{VA} / \mathrm{HC} \\
& \mathrm{STVA}=\mathrm{SC} / \mathrm{VA}
\end{aligned}
$$

\section{Tahap keempat}

Menghitung VAIC ${ }^{\text {TM }}$

$\mathrm{VAIC}^{\mathrm{TM}}=\mathrm{VACA}+\mathrm{VAHU}+\mathrm{STVA}$

\section{Kinerja Keuangan}

Kinerja keuangan perusahaan merupakan prestasi yang dicapai perusahaan dalam suatu periode tertentu yang mencerminkan tingkat kesehatan perusahaan tersebut dan atau merupakan ukuran kemampuan perusahaan dalam menciptakan nilai tambah bagi kelangsungan perusahaan di masa depan. 


\section{ROA (Retun On Asset)}

Retun On Asset (ROA) merupakan kemampuan perusahaan menghasilkan laba dari setiap asset yang ditanamkan dalam perusahaan. ROA diukur dengan prosentase perbandingan antara laba bersih dengan total asset (Bambang Riyanto 2008).

Rumus ROA adalah :

$$
\text { ROA }=\frac{\text { Laba bersih }}{\text { Total Asset }} \times 100 \%
$$

\section{ROE (Retun On Equity)}

Retun On Equity (ROE) merupakan kemampuan perusahaan menghasilkan laba dari setiap modal yang ditanamkan dalam perusahaan. ROE diukur dengan prosentase perbandingan antara laba bersih dengan modal sendiri (Bambang Riyanto, 2008).

Rumus ROE adalah :

$$
\mathrm{ROE}=\frac{\text { Laba bersih }}{\text { Modal Sendiri }} \times 100 \%
$$

\section{Analisis Deskriptif}

Analisa statistik deskriptif dilakukan untuk mencari nilai rata-rata, nilai maksimum, nilai minimum, dan standar deviasinya. Hal ini berlaku untuk semua variabel yang terdapat dalam penelitian baik variabel independen maupun variabel dependen. Data hasil analisis deskriptif akan disajikan dalam bentuk tabel sehingga mempermudah pembaca untuk memahami esensi hasil analisis.

\section{Uji Asumsi Klasik}

Sebelum dilakukan pengujian hipotesis terlebih dahulu dilaksanakan pengujian terhadap asumsi klasik. Model persamaan yang baik apabila memenuhi pengujian sebagai berikut :

\section{Uji Normalitas}

\section{Uji Normalitas atau Distribusi Normal}

Uji normalitas bertujuan untuk menguji apakah dalam model regresi, variabel pengganggu atau residual memiliki distribusi normal Ghozal (2011). Uji normalitas dapat dilakukan dengan cara uji statistik non-parametrik Kolmogorov Smirnov Test. Tingkat kesalahan (á) yang ditetapkan adalah sebesar 0,05 (á = 5\%). Penarikan kesimpulan dilakukan dengan ketentuan, jika nilai signifikansi > 0,05, maka data terdistribusi secara normal. Sebaliknya, jika nilai signifikansi $\leq 0,05$, maka data tidak terdistribusi secara normal. 


\section{Uji Autokorelasi}

Uji autokorelasi bertujuan untuk menguji apakah dalam suatu model regresi liniar terdapat korelasi antara kesalahan pengganggu pada periode t dengan kesalahan pengganggu pada periode t-1 (sebelumnya). Model regresi yang baik adalah regresi yang bebas dari autokorelasi (Ghozali, 2011). Salah satu untuk mengetahui apakah error berkorelasi atau tidak adalah dengan pengujian statistik Durbin-Watson, kriteria tidak terjadi autokorelasi dalam suatu model regresi adalah apabila du $<$ DW < 4- du (Ghozali, 2011).

\section{Uji Heteroskedastisitas}

Uji heteroskedastisitas bertujuan menguji apakah dalam regresi terjadi ketidaksamaan variance dari residual satu pengamatan ke pengamatan yang lain. Jika probabilitas variabel bebas $>$ 0,05 maka model regresi terbebas dari masalah heteroskedastisitas. Sebaliknya, jika probabilitas $\leq 0,05$ maka model regresi mengalami masalah heteroskedastisitas.

\section{Uji Statistik F}

Uji statistik F pada dasarnya menunjukkan apakah semua variabel independen atau bebas yang dimasukkan dalam model mempunyai pengaruh secara bersama-sama terhadap variabel dependen atau terikat. Kriteria pengujian adalah :

- Jika signifikasi $\mathrm{F} \leq 0,05$, maka model regresi adalah layak untuk penelitian

- Jika signifikasi F > 0,05, maka model regresi adalah tidak layak untuk penelitian.

\section{Koefisien Determinasi (Adjusted R2)}

Koefisien determinasi (R2) pada intinya mengukur seberapa jauh kemampuan model dalam menerangkan variasi variabel dependen. Nilai koefisien determinasi adalah antara nol dan satu. Nilai R2 yang kecil berarti kemampuan variabel-variabel independen dalam menjelaskan variasi variabel dependen amat terbatas. Nilai yang mendekati satu berarti variabel-variabel independen memberikan hampir semua informasi yang dibutuhkan untuk memprediksi variasi variabel dependen (Ghozali, 2011).

\section{Analisis Regresi}

Penelitian ini menggunakan analisis regresi linier sederhana karena hanya melibatkan satu variabel independen (X) dan dua variabel dependen (Y). Menurut Sugiyono (2005), analisis regresi linier digunakan untuk meramalkan keadaan (naik turunnya) variabel dependen dan melihat seberapa besar pengaruh variabel independen mempengaruhi variabel dependen. Penelitian ini meneliti hubungan antara intellectual capital yang dihitung dengan metode VAICTM dengan return on asset (ROA) dan return on equity (ROE). Model regresi tersebut adalah sebagai berikut:

$$
\begin{aligned}
& \mathrm{ROA}=\alpha+\beta 1 \text { VAIC }+\mathrm{e} \\
& \mathrm{ROE}=\alpha+\beta 1 \text { VAIC }+\mathrm{e}
\end{aligned}
$$


Keterangan :

ROA dan $\mathrm{ROE}=$ Variabel Dependen $(\mathrm{Y})$

$\alpha=$ Nilai konstanta

$\beta 1=$ Variabel Independen $(\mathrm{X})$

$\mathrm{VAIC}^{\mathrm{TM}}=$ Value added intellectual coefficient (VAICTM)

$\mathrm{e}=$ Error

\section{Uji Hipotesis}

Ketepatan fungsi regresi sampel dalam menaksir nilai aktual dapat diukur dari Goodness of Fit menurut Ghozali (2011). Secara statistik, setidaknya ini dapat diukur dari nilai koefisien determinasi dan nilai statistik t. Perhitungan statistik disebut signifikan secara statistik apabila nilai uji statistiknya berada dalam daerah kritis (daerah dimana Ho ditolak). Sebaliknya disebut tidak signifikan bila nilai uji statistiknya berada dalam daerah dimana $\mathrm{Ho}$ diterima.

\section{a. Koefisien Determinasi ( $\mathbf{R} 2)$}

Koefisien determinasi $\left(\mathrm{R}_{2}\right)$ pada intinya mengukur seberapa jauh kemampuan model dalam menerangkan variasi variabel dependen. Nilai koefisien determinasi adalah antara nol dan satu. Nilai R2 yang kecil berarti kemampuan variabel-variabel independen dalam menjelaskan variasi variabel dependen amat terbatas. Nilai yang mendekati satu berarti variabel-variabel independen memberikan hampir semua informasi yang dibutuhkan untuk memprediksi variasi variabel dependen.

\section{b. Uji signifikan parameter individual (Uji Statistik t)}

Uji statistik t pada dasarnya menunjukkan seberaa jauh pengaruh satu variabel independen secara individual (parsial) dalam menerapkan variasi variabel dependen Ghozali (2011). Uji t dapat juga dilakukan dengan melihat nilai signifikan t masing-masing variabel pada output hasil regresi yang menggunakan SPSS versi 16.0 dengan significant level 0,05 ( $\alpha=5 \%)$. Menentukan tingkat signifikansi Daerah penerimaan dan penolakan

- Ho1: tidak dapat ditolak jika signifikansi t hitung $\geq 0,05$, artinya tidak ada pengaruh yang signifikan antara intellectual capital (IC) terhadap return on asset (ROA).

- Ha1: tidak dapat ditolak jika, signifikansi t hitung <0,05, artinya ada pengaruh yang signifikan antara intellectual capital (IC) terhadap return on asset (ROA)

- H02: tidak dapat ditolak jika signifikansi t hitung $\geq 0,05$, artinya tidak ada pengaruh yang signifikan antara intellectual capital (IC) terhadap return on equity (ROE).

- Ha2: tidak dapat ditolak jika signifikansi t hitung < 0,05, artinya ada pengaruh yang signifikan antara intellectual capital (IC) terhadap return on equity (ROE).

\section{HASIL DAN PEMBAHASAN}

\section{Statistik Deskriptif}

Statistik deskriptif dari variabel-variabel penelitian (modal intelektual, return on asset, earning per share, return on equity). Secara lebih jelas statistik deskriptif dalam penelitian ini adalah : 
Tabel 1.

Descriptive Statistics

\begin{tabular}{|l|l|l|c|c|c|}
\hline & $\mathrm{N}$ & Minimum & Maximum & Mean & Std. Deviation \\
\hline VAIC & 72 & .16 & 14.53 & 3.3921 & 1.77878 \\
ROA & 72 & .64 & 5.55 & 1.9931 & 1.08042 \\
ROE & 72 & 5.41 & 37.65 & 16.4531 & 7.21741 \\
Valid N & 72 & & & & \\
(listwise) & & & & & \\
\hline
\end{tabular}

Berdasarkan tabel 1 menunjukan bahwa secara deskriptif data perusahaan perbankan dari tahun 2011-2013 pada VAIC ${ }^{\mathrm{TM}}$ memiliki nilai standar deviasi sebesar 1,778 dengan nilai mean sebesar 3,392. Sedangkan pada ROA nilai standar deviasi sebesar 1,08 dan lebih kecil dari nilai mean sebesar 1,99, pada ROE nilai standar deviasinya sebesar 7,217 lebih kecil dari nilai mean sebesar 16,45 . Hasil tersebut menunjukkan hasil yang baik sehingga data dalam penelitian ini mendukung hasil uji normalitas karena standar deviasi yang mencerminkan penyimpangan data relatif lebih kecil dari nilai mean yang berarti data tersebut cukup baik. Dengan demikian, nilai mean intellectual capital yang diukur dengan $\mathrm{VAIC}^{\mathrm{TM}}$ dengan tingkat penyimpangan rendah.

\section{Uji Normalitas}

Uji normalitas dilakukan dengan uji kolomogrov-smirnov. Apabila hasil dari pengujian kolomogrov-smirnov memiliki nilai $\geq 0,05$, maka dapat dikatakan bahwa unstandardized residualnya berdistribusi normal. Berikut merupakan hasil pengolahan data yang telah diolah:

Tabel 2.

\begin{tabular}{|c|c|c|c|}
\hline & & $\begin{array}{l}\text { Unstandardized } \\
\text { Residual }\end{array}$ & $\begin{array}{l}\text { Unstandardized } \\
\text { Residual }\end{array}$ \\
\hline $\mathrm{N}$ & & 72 & 72 \\
\hline \multirow[t]{2}{*}{ Normal Parameters ${ }^{a}$} & Mean & $\begin{array}{r}.000000 \\
0\end{array}$ & .000000 \\
\hline & Std. Deviation & $\begin{array}{r}1.04884 \\
768\end{array}$ & $\begin{array}{r}6.83739 \\
425\end{array}$ \\
\hline \multirow{3}{*}{$\begin{array}{l}\text { MostExtreme } \\
\text { Differences }\end{array}$} & Absolute & .131 & .103 \\
\hline & Positive & .131 & .103 \\
\hline & Negative & -.102 & -.075 \\
\hline Kolmogorov-Smirnov Z & & 1.113 & .874 \\
\hline Asymp. Sig. (2-tailed) & & .168 & .429 \\
\hline
\end{tabular}

Berdasarkan output pada tabel 2, diperoleh nilai Kolomogorov Smirnov Z untuk return on asset (ROA) sebesar 1.113 dengan Asymp. Sig (2-tailed) yaitu sebesar 0,168 atau sebesar 16,8 persen. Nilai ini lebih besar dari signifikansi yaitu 0,168>0,05 sehingga data terdistribusi secaranormal. Sedangkan untuk retun on equity (ROE) diperoleh nilai Kolomogorov Smirnov Z sebebsar 0,874 dengan Asymp. Sig(2-tailed) yaitu sebesar 0,429 atau sebesar 42,9 persen. Nilai ini lebih besar dari signifikansi yaitu 0,429>0,05 yang berarti hipotesis diterima. Sesuai dengan perumusan hipotesis maka hasil output data tersebut terdistribusi normal dan model regresi dapat digunakan dalam penelitian. 
Tabel 3.

Model Summaryb

\begin{tabular}{|c|c|r|r|c|}
\hline Model & $\mathrm{R}$ & $\mathrm{R}$ Square & $\begin{array}{c}\text { Adjusted R } \\
\text { Square }\end{array}$ & $\begin{array}{c}\text { Std. Error of the } \\
\text { Estimate }\end{array}$ \\
\hline & $.240^{\mathrm{a}}$ & .058 & .044 & 1.05631 \\
\hline
\end{tabular}

a. Predictors: (Constant), VAIC

b. Dependent Variable: ROA

Tabel 3.

Coefficients ${ }^{\star}$

\begin{tabular}{|c|c|c|c|c|c|}
\hline \multirow[b]{2}{*}{ Model } & \multicolumn{2}{|c|}{$\begin{array}{l}\text { Unstandardized } \\
\text { Coefficients }\end{array}$} & \multirow{2}{*}{$\begin{array}{l}\begin{array}{c}\text { Standardized } \\
\text { Coefficients }\end{array} \\
\text { Beta }\end{array}$} & \multirow[b]{2}{*}{$t$} & \multirow[b]{2}{*}{ Sig. } \\
\hline & $B$ & Std. Error & & & \\
\hline (Constant) & 1.499 & .270 & & 5.560 & .000 \\
\hline VAIC & .146 & .070 & .240 & 2.068 & .042 \\
\hline
\end{tabular}

a. Dependent Variable: ROA

Tabel 5

Model Summaryb

\begin{tabular}{|l|l|l|r|r|}
\hline Model & $R$ & $R$ Square & $\begin{array}{c}\text { Adjusted R } \\
\text { Square }\end{array}$ & $\begin{array}{c}\text { Std. Error of } \\
\text { the Estimate }\end{array}$ \\
\hline 1 & $.320 \mathrm{a}$ & .103 & .090 & 6.88606 \\
\hline
\end{tabular}

a. Predictors: (Constant), VAIC

b. Dependent Variable: ROE

Tabel 6

Coefficients $^{a}$

\begin{tabular}{|c|c|c|c|c|}
\hline \multirow[b]{2}{*}{ Model } & \multicolumn{2}{|c|}{$\begin{array}{l}\text { Unstandardized } \\
\text { Coefficients }\end{array}$} & \multirow{2}{*}{\begin{tabular}{|l|}
$\begin{array}{c}\text { Standardized } \\
\text { Coefficients }\end{array}$ \\
Beta \\
\end{tabular}} & \multirow[b]{2}{*}{$t$} \\
\hline & $B$ & Std. Error & & \\
\hline (Constant) & 12.046 & 1.757 & & 6.856 \\
\hline VAIC & 1.299 & .459 & .320 & 2.828 \\
\hline
\end{tabular}

a. Dependent Variable: ROE

\section{Uji Hipotesis}

Analisis regresi linier sederhana dilakukan untuk mengukur kekuatan hubungan antara satu variabel independen dan satu variabel dependen. Setelah dilakukan uji normalitas dan data dinyatakan terdistribusi normal, maka selanjutnya dilakukan uji Good of Fit untuk menguji ketepatan fungsi regresi sampel dalam penelitian ini yang dapat diukur dari nilai koefisien determinasi (R2) dan uji t.

Hasil analisis regresi linier sederhana yang tertera pada tabel diatas menunjukkan bahwa terdapat pengaruh yang positif dan signifikan antara intellectual capital terhadap 
return on asset (ROA) dan return on equity (ROE). Hal ini dibuktikan dengan model persamaan $\mathrm{ROA}=1,499+0,146 \mathrm{VAIC}+\mathrm{e}$. Nilai koefesien regresi pada return on asset (ROA) sebesar 0,146 yang menunjukkan nilai koefisien positif sehingga ada hubungan positif antara intellectual capital dengan return on asset (ROA), semakin tinggi nilai intellectual capital maka meningkat pula return on asset (ROA) dan $t$ hitung lebih besar dari t tabel $(2,068>1,960)$ dengan nilai signifikan signifikansi (p) lebih kecil dari taraf signifikansi 0,05 $(0,042<0,05)$ dan jika ditinjau dari besar pengaruh yang diberikan intellectual capital terhadap return on asset (ROA) sebesar 5,8\%, berdasarkan hasil tersebut maka hipotesis diterima karena hasilnya signifikan.

Berdasarkan hasil tersebut dapat disimpulkan bahwa intellectual capital yang dihitung berdasarkan $\mathrm{VAIC}^{\mathrm{TM}}$ berpengaruh secara positif dan signifikan terhadap return on asset (ROA). Pada model persamaan ROE $=12,046+1,299$ VAIC + e. Nilai koefesien regresi pada return on equity (ROE) sebesar 1,299 yang menunjukkan nilai koefisien yang positif sehingga ada hubungan positif antara intellectual capital dengan return on equity (ROE), semakin tinggi nilai intellectual capital maka meningkat pula return on equity (ROE) dan $\mathrm{t}$ hitung lebih besar dari t tabel $(2,828>1,960)$ dengan nilai signifikan signifikansi (p) lebih kecil dari taraf signifikansi $0,05(0,006<0,05)$ berdasarkan hasil tersebut maka hipotesis diterima karena hasilnya yang signifikan.

Dengan hasil ini dapat disimpulkan bahwa intellectual capital yang dihitung berdasarkan VAIC ${ }^{\mathrm{TM}}$ berpengaruh secara positif dan signifikan terhadap return on equity (ROE) dan jika ditinjau dari besar pengaruh yang diberikan intellectual capital terhadap return on equity (ROE) sebesar $10,3 \%$.

\section{Diskusi}

\section{Pengaruh Intellectual Capital Terhadap ROA}

Dari penelitian yang telah dilakukan, diperoleh hasil bahwa intellectual capital memiliki pengaruh yang positif terhadap return on asset (ROA) industri perbankan yang terdaftar di Bursa Efek Indonesia. Kondisi ini terjadi karena intellectual capital merupakan kekayaan intelektual yang berpusat pada sumber daya manusia yang berfungsi meningkatkan daya saing sumber daya manusia yang dimiliki oleh perusahaan. Jika kemampuan sumber daya manusia semakin baik, maka diharapkan akan menghasilkan kinerja yang baik bagi perusahaan, sehingga profitabilitas Return On Asset semakin meningkat.

Berdasarkan teori resource-based theory, perusahaan akan unggul dalam persaingan usaha dan mendapatkan kinerja keuangan yang baik dengan cara memiliki, menguasai dan memanfaatkan aset-aset strategis yang penting (aset berwujud dan tidak berwujud). Intellectual capital diyakini dapat berperan penting dalam peningkatan nilai perusahaan maupun kinerja keuangan (ROA).

Hasil ini mendukung penelitian Ulum et al (2008), dan Kurniawan (2013), menunjukkan bahwa Intellectual Capital berpengaruh positif terhadap ROA. Tetapi hasil ini 
tidak sejalan dengan penelitian Rismawati dan Sanjaya (2012), yang menyatakan Intellectual Capital tidak berpengaruh signifikan terhadap kinerja perusahaan (ROA).

\section{Pengaruh Intellectual Capital Terhadap ROE}

Intellectual Capital berpengaruh positif signifikan terhadap ROE, hal ini dapat diartikan bahwa semakin tinggi Intellectual Capital, maka ROE semakin meningkat. Kondisi ini terjadi karena intellectual capital yang semakin meningkat, maka perusahaan sudah menggunakan modalnya lebih efektif untuk meningkatkan kemampuan sumber daya manusia, sehingga kinerja karyawan untuk menghasilkan laba semakin meningkat.

Berdasarkan resource-based theory, perusahaan akan unggul dalam persaingan usaha dan mendapatkan kinerja keuangan yang baik dengan cara menggunakan modalnya untuk kepentingan perbaikan sumber daya manusia yang merupakan salah satu modal perusahaan. Intellectual capital diyakini dapat berperan penting dalam peningkatan nilai perusahaan maupun kinerja keuangan (ROE).

Hasil ini mendukung penelitian Fajarini dan Firmansyah (2012), membuktikan bahwa Intellectual Capital berpengaruh positif terhadap ROE. Semakin tinggi Intellectual Capital, maka ROE semakin meningkat. Tetapi hasil penelitian ini tidak sejalan dengan penelitian Kuryanto dan Syafruddin (2008), dan Wijayanti (2012) membuktikan bahwa Intellectual Capital tidak berpengaruh signifikan terhadap ROE.

Nilai VAIC ${ }^{\mathrm{TM}}$ pada perusahaan perbankan memiliki nilai rata-rata sebesar 3.3921 yang merupakan jumlah presentase rata-rata penerapan konsep intellectual capital pada perusahaan perbankan. Nilai VAIC $^{\mathrm{TM}}$ terendah sebesar 0,16 hal ini menunjukkan bahwa perusahaan perbankan di Indonesia kurang mampu untuk mengelola kekayaan intelektualnya. Nilai tertinggi untuk VAIC ${ }^{\mathrm{TM}}$ sebesar 14,53 , yang berarti perusahaan yang memiliki nilai tertinggi ini mampu untuk mengelola kekayaan intelektual capitalnya dengan sangat baik dan bahkan jauh diatas rata-rata dari perusahaan lainnya.

Nilai koefisien determinasi (R2) yang diperoleh dalam penelitian ini pada return on asset (ROA) dan return on equity (ROE) sebesar 5,8\% dan 10,3\% yang berarti bahwa variabel intellectual capital suatu perusahaan perbankan mempengaruhi ROA (Return on Asset) sebesar 5,8\% dan mempengaruhi return on equity (ROE) sebesar 10,3\%. Hasil penelitian ini sesuai dengan penelitian yang dilakukan oleh Ivan Herdyanto dan Mohamad Nasir (2013) yang menunjukkan menunjukkan bahwa IC memberikan pengaruh positif dan signifikan terhadap ROA, ROE.

Adanya pengaruh intellectual capital terhadap kinerja keuangan perusahaan bisa dikarenakan perusahaan tersebut memanfaatkan human capital, structural capital, dan sumber daya fisik yang dimilikinya dengan baik, sehingga dapat memberikan nilai tambah (value added) dan dapat meningkatkan kinerja keuangan perusahaan.

Intellectual capital merupakan komponen yang dimiliki oleh suatu perusahaan dalam mengukur nilai sumber daya manusia didalamnya. Namun, pada kenyataannya peran manusia 
sebagai human capital belum diperlakukan sebagaimana aset yang lainnya yang perlu dibina dan dikembangkan. Intellectual capital adalah hasil penggabungan unsur-unsur utama organisasi yang berbasis pengetahuan yang meliputi, human capital, structural capital dan customer capital untuk menciptakan value added yang pada akhirnya memberikan manfaat ekonomi jangka panjang bagi perusahaan sebagai keunggulan organisasi dalam persaingan dunia usaha. Intellectual capital mempunyai hubungan dan peran nyata serta positif baik dalam strategi dan operasional dalam menciptakan nilai pada kemampuan perusahaan untuk menciptakan keunggulan bersaing, sehingga manajemen perlu untuk menaruh perhatian dan mengelola intellectual capital.

\section{KESIMPULAN}

Berdasarkan hasil analisis penelitian dan pembahasan yang telah diuraikan sebelumnya dapat diambil kesimpulan sebagai berikut:

1. Intellectual Capital berpengaruh positif signifikan terhadap return on asset (ROA). Jika kemampuan sumber daya manusia semakin baik, maka diharapkan akan menghasilkan kinerja yang baik bagi perusahaan, sehingga profitabilitas Return On Asset semakin meningkat. Pengaruh positif ini dibuktikan dengan nilai koefesien regresi yang bernilai positif dan hasil yang signifikan. Hal ini berarti bahwa semakin tinggi nilai intellectual capital sebuah perusahaan perbankan maka return on asset (ROA) suatu perusahaan keuangan tersebut semakin meningkat.

2. Intellectual Capital berpengaruh positif signifikan terhadap return on equity (ROE). Jika kemampuan sumber daya manusia semakin baik, maka diharapkan akan menghasilkan kinerja yang baik bagi perusahaan, sehingga profitabilitas return on equity semakin meningkat. Pengaruh positif ini dibuktikan dengan nilai koefesien regresi yang bernilai positif dan hasil yang signifikan. Hal ini berarti bahwa semakin tinggi nilai intellectual capital sebuah perusahaan perbankan maka return on equity (ROE) suatu perusahaan keuangan tersebut semakin meningkat.

Perusahaan yang memiliki nilai intellectual capital yang baik berarti perusahaan tersebut telah memaksimalkan perhatiaannya terhadap ketiga komponen intellectual capital (IC) yang terdiri dari (1) human capital dimana perusahaan harus memperhatikan kinerja karyawannya, (2) structural capital yang merupakan infrastruktur yang dimiliki perusahaan, (3) customer capital yang merupakan orang-orang yang berhubungan dengan perusahaan.

\section{Daftar Pustaka}

Chen, M.C., Cheng, S.J. \& Hwang, Y. (2005). An Empirical Investigation of relationship between Intellectual Capital and Firm's market value and Financial Performance. Journal of Intellectual Capital. Vol.6 No.2.

Ulum, I. (2008). "Intellectual Capital Performance Sektor Perbankan di Indonesia". Jurnal Akuntansi dan Keuangan Vol. 10, No.2, November 2008, Pp. 77-84. 
Barney, J.B. (2001). Is the resource based "view" a useful perspective for strategic anagement research? Yes. Academy of Management Review, 26(1):41-56

Ulum, I. (2009). “Intellectual Capital : Konsep dan Kajian Empiris”. Yogyakarta: PT. Graha Ilmu.

Ulum, I. (2008). "Intellectual Capital Performance Sektor Perbankan di Indonesia". Jurnal Akuntansi dan Keuangan Vol. 10, No.2, November 2008, Pp. 77-84.

Sugeng, ND. Imam. (2002). Mengukur dan Mengelola Intellectual capital. Jurnal Ekonomi dan Bisnis Indonesia (JEBI) Fakulatas Ekonomi UGM. Vol. 15. No. 2. Pp. 479-488.

Mulyadi. (2007). Sistem Perencanaan dan Pengendalian Manajemen : Sistem Pelipatganda Kinerka Perusahaan. Jakarta: Salemba Empat

Sukhemi. (2007). Evaluasi Kinerja Keuangan. Akademika Jurnal Akuntansi dan Manajemen Vol 1.

Dendawijaya, Lukman. (2009). Manajemen Perbankan. Edisi Kedua. Jakarta: Ghalia Indonesia

Aristya, D. (2010). “Analisis Pengaruh Ukuran Perusahaan, Kecukupan Modal, Kualitas Aktiva Produktif, dan Likuiditas terhadap Kinerja Keuangan Bank Syariah”. Semarang : UNDIP.

Malayu S.P. Hasibuan.(2006). Dasar-Dasar Perbankan. Jakarta: PT. Bumi Aksara.

Wijaya, N. (2012). Pengaruh Intellectual Capital terhadap Kinerja Keuangan dan Nilai Pasar Perusahaan Perbankan dengan Metode Value Added Intellectual Coefficient. Jurnal Bisnis dan Akuntansi 14(3):157-180.

Santoso, S. (2012). Pengaruh Modal Intelektual dan Pengungkapannya Terhadap Kinerja Perusahaan. Jurnal Akuntansi Dan Keuangan 14(1): 16-31.

Comepa, Narongsak and Kongkiti Phusvat. (2011). An Empiricial Study Of The Relationship Between Intellectual Capital And The Performance Of a Manufacturing Firm. Journal Kasetsart University. Thailand.

Kurniawan, I. S. (2013). Intellectual Capital terhadap Kinerja Keuangan Perusahaan Publik di Indonesia. Jurnal Keuangan dan Perbankan. Vol. 17. No. 1. Pp. 23 - 25.

Fajarini W., I. S., dan Firmansyah, R. (2012). Pengaruh Intellectual Capital terhadap Kinerja Keuangan Perusahaan (Studi Empiris Perusahaan LQ 45). Jurnal Dinamika Akuntansi. Vol. 4. No. 1. Pp. 1 - 12.

Wijayanti, P. (2012). Pengaruh Intellectual Capital terhadap Harga Saham Melalui Kinerja Keuangan pada Perusahaan Perbankan yang Terdaftar di Bursa Efek Indonesia (BEI) pada Tahun 2009 - 2011. Jurnal Akuntansi dan Keuangan. Vol. 7. No.2. Pp. 65-77.

Herdyanto, i., \& Nasir, M. (2013). Pengaruh Intellectual Capital pada Financial Performance. Diponogoro Journal of Accounting. Vol. 2, No. 3, Pp.1-10.

Rismawati dan Sanjaya. (2012). Pengaruh Intellectual Capital terhadap Kinerja Keuangan daPada Perusahaan Publik di Indonesia. Jurnal Bisnis dan akuntansi. Vol. 14. No.1. Pp.157 - 180.

Riyanto, Bambang. (2008). Dasar-Dasar Pembelanjaan Perusahaan. Yogyakarta: BPFE.

Ghozali, Imam. 2011. Aplikasi Analisis Multivariat Dengan Program SPSS. Semarang: Badan Penerbit Universitas Diponegoro

Sugiyono. 2005. Memahami Penelitian Kualitatif. Bandung: CV. Alfabeta. 
Kuryanto, B., dan Syafruddin, M. 2008. Pengaruh modal Intelektual terhadap kinerja perusahaan. Simposium Nasional Akuntansi XI.

Herdyanto, i., \& Nasir, M. (2013). "Pengaruh Intellectual Capital pada Financial Performance".Diponogoro Journal of Accounting. Vol. 2, No. 3, Pp.1-10. 